\title{
The Historical Review of the 1755 Lisbon Tsunami
}

\author{
Angela Santos ${ }^{1}$ and Shunichi Koshimura ${ }^{2}$ \\ 1. Centre for Geographical Studies, Institute of Geography and Spatial Planning, Universidade de Lisboa, Edifício da Faculdade de \\ Letras, Alameda da Universidade, Lisboa 1600-214, Portugal \\ 2. Laboratory of Remote Sensing and Geoinformatics for Disaster Management, International Research Institute of Disaster Science, \\ Tohoku University, Aoba 6-6-03, Aramaki, Aoba-ku, Sendai 980-8579, Japan
}

\begin{abstract}
The original accounts reporting the 1755 Lisbon Tsunami were compiled, focusing on the descriptions related to the tsunami parameters, damage and fatalities in the affected regions (Atlantic Northeast and Caribbean). The accounts show the tsunami reached the southwest municipalities of Portugal in less than 30 minutes after the earthquake, and about one hour later the entire coasts of Portugal, Gulf of Cadiz (Spain) and Morocco were hit by the first tsunami waves. The tsunami took about five hours to reach Ireland and UK, and hit the Caribbean region about 9-10 hours after the earthquake. In addition, significant damage and fatalities were reported in Portugal (Peniche, the Lisbon Metropolitan Area and seven coastal areas in the south), Spain (Cadiz) and in all Morocco coastline, including Marrakech which is located about $200 \mathrm{~km}$ inland. In Ireland, UK and the Caribbean minor damage was observed, and no fatalities were reported.
\end{abstract}

Key words: The 1755 Lisbon Tsunami, historical accounts, tsunami parameters, fatalities, damage.

\section{Introduction}

The historical accounts reporting the 1755 Lisbon Tsunami are quite vast and their full compilation and interpretation have been difficult. Several scholars have been trying to compile and understand the physical characteristics of this tsunami, as discussed by [1]. The main obstacle has been the language, since the reports are written in different languages: In Portugal they are mostly written in Old Portuguese, contemporary from the 18th century, while in Spain the accounts are written mostly in Spanish and in Morocco in Arabic. [2] compiled the available data in English, but there were many unknown features of this historical event. More recently, [3] pointed out the problem of analyzing historical tsunamis, and the need of tsunami experts to re-evaluate tsunamis which were not completely understood. Therefore, in order to

Corresponding author: Angela Santos, postdoctor, research fields: tsunami engineering, tsunami hazards and risk. E-mail: angela.santos@campus.ul.pt. This research was supported by the TsuRiMa Project-TSUnami Risk Management for Spatial Planning and Civil Protection (PTDC/CSGEO/118992/2010), funded by the FCT (Foundation of Science and Technology), Portugal. provide the full tsunami descriptions in all the affected areas by this historical event, [4] compiled and translated to English all the available data. Then, for the first time ever, significant developments in the comprehensive analyses of this historical tsunami were possible: By estimation a magnitude 8.7 earthquake, the most probable tsunami source area was pointed out at the Gorringe Bank [1]; has a consequence, and by the use of the tsunami numerical model, it was possible to conduct a tsunami hazard assessment in Portugal, by the combination between travel times and maximum water level [5]; the most probable time of the earthquake was calculated has 10:15-10:16 UTC [5]. Furthermore, by considering a scenario similar to the 1755 Lisbon Tsunami, the calculation of the inundated areas at the municipality scale in Portugal, and by using the tsunami numerical model, allowed a more detailed analysis of the impact of this king of natural disaster: In Figueira da Foz the tsunami would reach as far as $10 \mathrm{~km}$ upstream de Mondego River [6]; in Setubal the tsunami would inundate the urban area of the city as far as $400 \mathrm{~m}$ 
inland [7], potentially affected 481 buildings [8], being two buildings associated with the emergency response service. Since many details related to the historical accounts in Portugal have remained to be analyzed, [9] focused on the analysis of the tsunami parameters in Portugal, while [10] focused on the analysis of the reports related to damage and fatalities.

It has been known that the 1755 Lisbon Tsunami hit several countries in the Atlantic Ocean (Portugal, Spain, Morocco, Ireland, UK and the Caribbean region). However, the full historical accounts have not been analyzed. Therefore, the objective of this study is to provide the compilation and interpretation of all the tsunami reports, including the tsunami parameters, damage and fatalities.

\section{The Eyewitness' Accounts}

\subsection{Accounts in the Caribbean}

The tsunami accounts in the Caribbean are presented below, mostly compiled from Ref. [11], and the location of places is shown in Fig. 1.

Santiago de Cuba: "At 3 pm, the sea almost completely inundated Santiago de Cuba”.

St. Martin: "The sea retired so far that a sloop riding at anchor in 15 feet [ $4.5 \mathrm{~m}$ ] of water, was laid dry on her broadside".

Saba: "waves 21 to 25 feet [Eng. feet 6.3-7.5 m]".

Antigua: "[seawaves] were first noticed at 7:38 pm, Lisbon time. The sea rose 12 feet [3.6 m] several times, and every 5 minutes afterwards until $10 \mathrm{pm}$, when it rose 5 feet $[1.5 \mathrm{~m}]$ without any violent disturbance on the surface of the water".

Martinique: "The flux and reflux of the sea, it was in some places dry for a mile [English mile $=1.5 \mathrm{~km}$ ]; and in others, flowed into the upper rooms of houses and destroying much coffee".

Barbados: “At 5:14 pm Lisbon time, the sea flowed over the wharves and streets, and continued ebbing and flowing for 8 hours"; "At Barbadoes [...] the water rose 20 feet [ $6 \mathrm{~m}]$ at Carlisle Bay". "At 2 pm the [...] waters rose 5 feet $[1.5 \mathrm{~m}]$. [...] This flux and reflux continued every half of quarter of an hour till 10 in the night. In the 8 hour time the movements of fluxes and refluxes repeated 64 times” [12].

\subsection{Accounts in Ireland and UK}

The transcription of the original accounts in Ireland and in the UK is below and Fig. 2 shows the location of places where the tsunami was observed.

Kinsale: "[...] between the hours of 2 and 3 afternoon, $[\ldots]$ a large body of water suddenly poured into this harbour, with such rapidity that it broke the cables of two sloops, each moor'd with 2 anchors, and of several boats $[\ldots]$ which were carried up, then down, the harbour [...]. By the direction, in which the sloops were carried down, I imagined they and several boats would have ran soul of each other [...]. This was

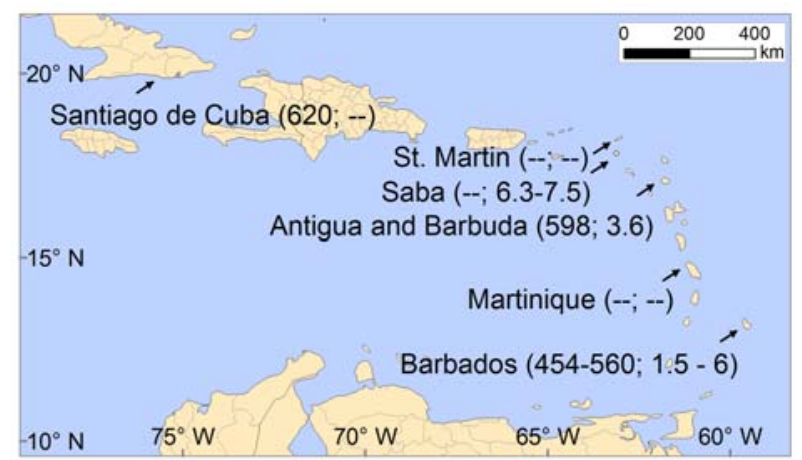

Fig. 1 Location of the places with tsunami accounts in the Caribbean. Also included is (travel time in minutes; run-up in meters), as summarized in Table 1.

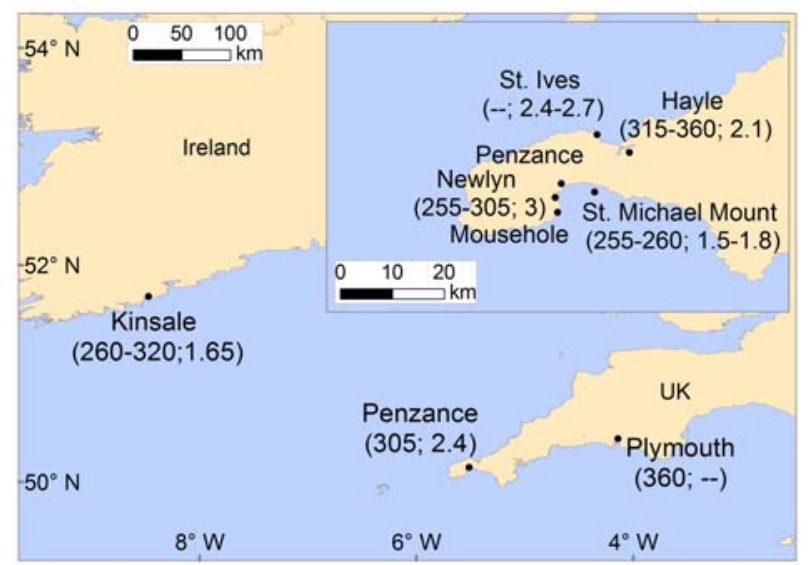

Fig. 2 Location of the places with tsunami accounts in the UK and Ireland. Inset plot shows details on the Cornwall. Also included is (travel time in minutes; run-up in meters), as summarized in Table 1. 
repeated several times; [...] The Reverend Mr. Keef says, the perpendicular rise of the water at his quay was five feet and a half [1.65 m], as he measured it, and I am told it was much higher at the market-quay, which it overflowed, and poured at the market-place [...]; The agitations of the water were communicated some miles up the river, but as in the harbour, were mostly perceivable in the shallowest places. The successive risings and fallings of the water continued about 10 minutes [...] and I am told it continued its alternate ebbs and flows till three in the morning. [...]" [13].

Cornwall: “[...] A little after two o'clock in the afternoon [...] the sea was observed at Mount-pier to advance suddenly [...]. It continued to swell and rise for the space of ten minutes; [...] and so it continued alternately to rise and fall between five and six feet, in the same space of time. The first and second fluxes and refluxes were not so violent at the Mount-pier as the third and forth, [...] and the whole commotion ceased [...] five hours and an half after it began. Penzance $[\ldots]$ the reflux was first observed here 45 minutes after two. [...] Here the greatest rise was eight feet [2.4 m], and the greatest violence of the agitation about three o'clock” [14].

Newlyn: "The flux was observed first $[\ldots]$ and came in $[\ldots]$ nearly at the same time as at the Mount and Penzance. [...] After a few advances and retreats at their greatest violence, in the same space of time as at the Mount, the sea grew gradually quiet, after it had rose $[\ldots]$ ten feet $[3 \mathrm{~m}]$ perpendicular at least. [...] The agitations of the sea at Mousehole [...] did not materially differ from those at Newlyn. [...] At Penzance there was no damage, nor, [...] at Newlyn, where their boats are much more numerous. [...] at the pier of St. Ives, it rose betwixt eight and nine feet [2.4-2.7 m] [...]”[14].

Hayle: “[...] the agitation did not make its appearance till an hour and a little more after the ebb began which must be full an hour later than us [...]. In this inland half-tide harbour it continued visible but an hour and half; the greatest flux was about the middle of that time, the surge being at that time seven feet high [2.1 m] [...]" [14].

Plymouth: "[...] about 4 pm we had $[\ldots]$ an extraordinary boar [...]. The sea seemed disturbed about 20 minutes before [...]. The tide had made a very extraordinary out (or recess) almost immediatly after high water (about 4pm) left both the passage-boats, with some horses, and several persons, at once quite dry in the mud though the minute or two before in four or five feet [1.2 -1.5 m] water: in less than eight minutes the tide returned with the utmost rapidity, and floated both the boats again, so that they had near six feet $[1.8 \mathrm{~m}]$ of water. The sea sunk and swelled, though in a much less degree, for near half an hour longer. This boar drove several ships from their moorings, and broke some of the hawsers, and twirled the ships and vessels round in a very odd manner. [...]" [15].

\subsection{Accounts in Spain}

The tsunami accounts in Spain were mostly compiled from Ref. [16]. The text is in Portuguese therefore the translation to English is presented below. In addition, Fig. 3 shows the location of places where the tsunami was observed.

Bilbau: "Agitation of the sea".

Santander: "The water retired and rose for 3 times".

Viveiro: "The sea rose and retreated for 3 times".

Ferrol: "Movements of the ships at the port".

Betanzos: "During the rest of the day, there were fluxes and refluxes on the ria".

Coruna: "The sea grew and decreased 4 times in less than $1 \mathrm{~h}$ ".

Corcubion: "Arrived 2 h 15 min later. Movements till the night”.

Pontevedra: "The sea grew suddenly till the level of the high tide, for three times".

Redondela: "Entered half a legoa, inundating the warehouses and fishery tools".

Baiona: "Diverted a boat cape sized on the ria". 


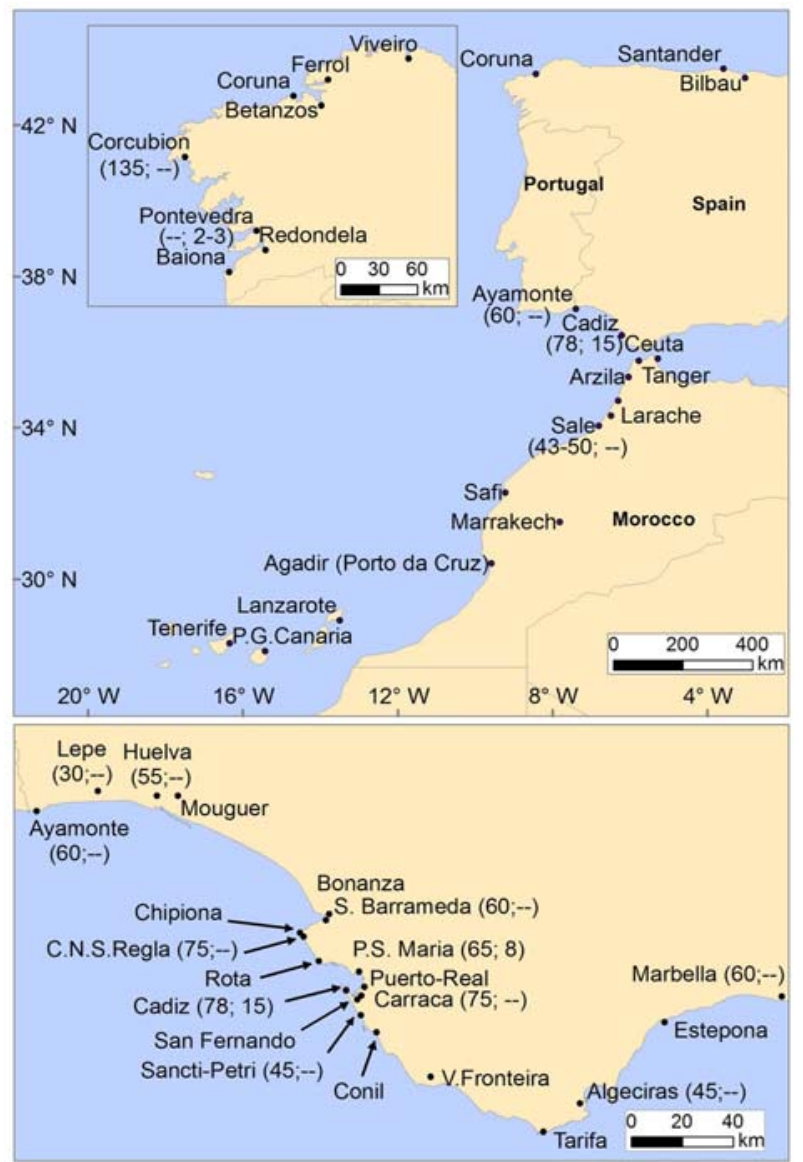

Fig. 3 Location of the places with tsunami accounts in Spain and Morocco. Upper, inset plot shows details in Coruna. Lower plot shows details in the Gulf of Cadiz. Also included is (travel time in minutes; run-up in meters), as summarized in Table 1.

Ayamonte: "Arrived 1 hour later. 5 times was repeated. Invaded the beaches and made damaged in the fishery".

Lepe: "Arrived 30 minutes later. There were 3 waves”.

Huelva: "Arrived 55 minutes later. Some streets were inundated. The movement persisted till $24 \mathrm{~h}$ ”.

Moguer: "Big wave of salty water on the ria".

Sanlucar de Barrameda: "Arrived 1 hour later. The streets were inundated. 5 fishery vessels were destroyed".

Bonanza: "Ship loaded with wheat was pushed to a sand bank".

Chipiona: "Inundated the beach and the streets".

Convent of N.S. Regla: “Arrived 1 h 15 min later.
The waves hit the walls of the convent. There was a repetition $2 \mathrm{~h}$ 15min later".

Rota: "Broke up the pier and entered on same streets".

Puerto de Santa Maria: “Arrived 65 min later. The houses were inundated and caused damaged on the pier". Waves of up to $8 \mathrm{~m}$ in height which destroyed the harbor and scattered numerous boats in the village and in the surrounding fields [17].

Puerto Real: "Introduced smoothly on the streets".

Carraca: "Arrived 1 h 15 min later. The movements lasted all afternoon”.

Cadiz: "Arrived 78 min later. The neighborhoods of the city were inundated. It lasted till midnight. [...] a wave $[\ldots]$ was at least fifty feet $[15 \mathrm{~m}]$ higher than common. [... ] It came against the west part of the town, which is very rocky: the rocks abated a great deal of its force. At last it came upon the walls, and beat in the breast-work, and carried pieces of eight or ten ton weight, forty and fifty yards [35.7-45.7 m] from the wall, and carried away the sand and walls, but left the houses standing, so that only two or three persons were drowned. [...] These waves came in this manner four or five times, but with less force each time; and about one the sea grew more calm, but was still in a boiling motion. Everything was washed off the mole. [...] The walls have suffered very much. [...]" [18]. "[...] the sea [...] retired, and in a few minutes return with such a impetus, that it was feared the inundation of Cadiz [...]" [12].

San Fernando: "Severe damages on the beach houses".

Sancti-Petri: “Arrived 45 minutes later, inundated the river and diverted the boats".

Conil: "Entered 1 legoa and a half [6750 m] inland. Drowned 599 head of cattle".

Vejer de la Fronteira: "The sea waters entered the marshs for 1 legoa and a half [6750 m]”.

Tarifa: "The wreck of 3 vessels".

Algeciras: "Arrived 45 minutes after. The reflux lasted till the night". 
Estepona: "Small alterations of the sea".

Marbella: “Arrived 1 hour later. The sea grew 20 passos and lowered 20”.

Ceuta: "lasted till the next day".

Lanzarote: "Some salt-marshs were destroyed".

Palmas de Gran Canarias: “On the Puerto de la Luz one chapel was inundated. Three repetitions”.

Santa Cruz de Tenerife: “The waters rose, but not everybody noticed that”.

\subsection{Accounts in Morocco}

The accounts in Morocco were compiled from [19]. The author published eight texts in Portuguese: The 1st text was printed in Sevilla, written by an anonymous author. The 2nd was written by Father Guardian of the Meknes Real Convent; the 3rd document was published by Magaly Morsy, and it belongs to the national Library of Paris. The 4th text was published in Rome and it is available on the General Library and Archives of Tentuan. The 5th document was published by Magaly Morsy and the author of this document is an English merchant. The 6th text gives an account by Rabbi Habib Bar Yussef Toledano. The 7th document consists on an account by Mohammad Adu'ayyef Al-ribati. The 8th text is referred by al-Qadirl, written in Arabic and is very similar to the 7th text. The translation in English is presented below. In Fig. 3 is shown the location of the places with tsunami reports.

Tanger: “[...] the sea rose in a way never seen before, passed the rampart and inundated the houses and the fields, submerging and destroying many vessels and the people that were inside them; and when it lowered down left the streets and the fields full of debris and fish [...]" (1st text). “[...] the earthquake and the tide wave triggered much damage to the houses and buildings, causing the death of many people [...]" (2nd text). "[...] the sea had inundated the villages with the loss of boats and people [...]" (4th text). "[...] the sea rose till the ramparts, something never seen before, and returned lower down with the same rapidity that it rose, till the place where the big vessels anchor on the bay, leaving on the jetty a big quantity of sand and fish. These movements of the sea were repeated 18 times and continued until 6 in the afternoon, although not with such a violence as the beginning. " (5th text).

Arzila: "[...] the sea rose in a way never seen before, passed the rampart and inundated the houses and the fields, submerging and destroying many vessels and the people that were inside them; and when it lowered down it left the streets and the fields full of debris and fish [...]" (1st text). "[...] the sea inundated more than half of the city, and like the earthquake, killed many people and destroyed many houses and buildings, sank some vessels and with such an impetus launched into the middle of the city a big Pingue Ingles [type of vessel] that broke apart and opened in the middle, nobody from the crew died [...]” (2nd text). “[...] the sea inundated more than half of the city and dragged to the middle of the rampart an English vessel that stayed there on the dry land [...]” (3rd text). “[...] the sea had inundated the villages with the loss of many boats and people [...]" (4th text). "[...] the rising of the waters did not make so much damage [as in Tanger], although the Moors that were outside of the rampart had drowned and the water entered by one of the city's doors far away. The waters rose with such an impetus that launched into the air a ship that was on the bay and (when the waters return to their center) fell dawn with such a force that it broke apart into pieces; and a boat was found a distance of 2 musket shots from the sea [...]" (5th text).

Larache: "[...] the sea rose in a way never seen before, passed the rampart and inundated the houses and the fields, submerging and destroying many vessels and the people that were inside them; and when it lowered down left the streets and the fields full of debris and fish [...]" (1st text). "[...] the earthquake and the tide wave triggered much damage to the houses and buildings, causing the death of many 
people $[\ldots]$ " (2nd text). "[...] the sea had inundated the villages with the loss of many boats and people [...]" (4th text).

Mehdiya: "[...] the sea rose in a way never seen before, passed the rampart and inundated the houses and the fields, submerging and destroying many vessels and the people that were inside them; and when it lowered down it left the streets and the fields full of debris and fish [...]" (1st text). "[...] the earthquake and the tide wave triggered much damage to the houses and buildings, causing the death of many people [...]" (2nd text). "[...] the sea had inundated the villages with the loss of many boats and people [...]" (4th text).

Sale: "[...] the sea inundated the streets and warehouses and snatched 3 boats with more than 200 Moors, that were passing through the river from one city to the other and drowned them into the depth, and nobody escaped [...]" (2nd text). "[...] the inundation that came from the sea, submerged the boats and people, the water rising immensely and when ebbing left the city and the fields with fish [...]" (4th text). "[...] the waters rose with such a rapidity that entered the city and when they recessed left big quantity of fish on the streets and many people drowned. 2 boats capsized on the river, and all the people that were on board drowned; and a big number of camels that, at that moment, were being transported to Morocco, were dragged by the torrent” (5th text). "[...] After the earthquake, about 15 minutes, we heard a big noise in the sea and soon after the water disappeared [...]. Because of this the boats were standing on dry land, since the water had disappeared. Then the water came, in an instant and with great furor, overcame the usual level, drowned everybody that was on the boats and also the people neighboring the beach. [...]" (6th text). "[...] in Sella the sea pulled the water to the bottom and disappeared. So, people left the city to watch the sea, but the sea disrupted on the land and killed all those that went to watch the sea. [...]" (7th text).

Safi: "Losses that were aggravated by the alterations of the sea, that from 10 in the morning till 6 in the afternoon, continued to rise with such a impetus and recessing with the same rapidity, leaving uncovered the bottom of the ports, where the ships and vessels were anchored; some of them sank and others were damaged with the people on board, and left the streets and fields full of debris and fish.” (2nd text). "[...] the sea, so violently agitated like there was no memory, broke apart the boats that were colliding into each other [...]. The constructions that were along the coast were destroyed with the violence of the waves; the port area was covered suddenly by corpses and dead fish [...]" ( 3rd text). "[...] and many people died, because the sea inundated the ports and covered the debris and fish the entrances and the fish" (4th text). "[...] the sea rose till the great mosque, that is located inside the city and on a great distance from the sea [...]" (5th text).

Marrakech: "[...] the violent flood of the Trancif river that passes through that zone, invaded the City Doors and drowned many people [...]” (1st text). “[...] [the sea] engulfed a caravan that was on the way to Marrakech and many people and animals died and the sea pushed to the high lands many boats and ships, that were later found far away from the coast $[\ldots]$ ” (7th text).

Agadir: "Losses that were aggravated by the alterations of the sea, that from 10 in the morning till 6 in the afternoon, continued to rise with such a impetus and recessing with the same rapidity, leaving uncovered the bottom of the ports, where the ships and vessels were anchored; some of them sank and others were damaged with the people on board, and left the streets and fields full of debris and fish.” (2nd text). "[...] the sea, so violently agitated like there was no memory, broke apart the boats that were colliding into each other [...]. The constructions that were along the coast were destroyed with the violence of the waves; the port area was covered suddenly by corpses and dead fish [...]" (3rd text). "[...] and many people died, because the sea inundated the ports and covered 
the debris and fish the entrances and the fish” (4th text).

\subsection{Accounts in Portugal}

The historical accounts in Portugal reporting the tsunami are vast and complete. Most of the original accounts were already compiled and translated to English [1, 9-10].

However, the accounts in Benavente (Point 13 in Fig. 4) and at Madeira and Azores Islands have not being analyzed yet. Therefore, the reports on these places are presented below. Fig. 4 shows the location of all the places in Portugal where tsunami reports are available.

13-Benavente: "Nobody died [...]. When the first earthquake happened it was low tide, and then it filled till high tide, filling and empting for 3 times (...).This Civil Parish has 1,156 men, 1,052 women (...)” [20].

Porto Santo, Madeira Islands: “[...] the sea [...] got out of its limits, by 10 in the morning came to the land from the Ilheu de Cima, introducing its waters through the town $[\ldots]$ and it seems that only one house was overthrown by the sea [...]" [12].

Funchal, Madeira Islands: “[...] About an hour and half after the shock had ceased, the sea [...] entered into the city. It arose full fifteen feet $[4.5 \mathrm{~m}]$ perpendicular above high water mark, although the tide, which ebbs and flows here seven feet [2.1 m], was then at half ebb. The water immediately receded again, and, after having fluctuated four or five times between high water and low water mark, the undulations continually decreasing. [...] ” [21]. “[...] at Funchl the sea rose 5 meters above high tide and on the north of the island [...] the sea retreated about 100 $\mathrm{m}$, leaving on dry land a large quantity of fish.” [12].

Angra do Heroismo, Azores Islands: “[...] suddenly at about ten hours in the morning, in three continuous waves, that were elevated to more than three meter above mean [sea] level, demolishing many houses, following an ebb so extraordinary that at Angra some anchors of the vessels were uncovered, and the ships almost touch the keel at the bottom of the sea” [12].

\section{Interpretation of the Eyewitnesses' Accounts}

\subsection{Tsunami Parameters}

The summary of the tsunami parameters in the

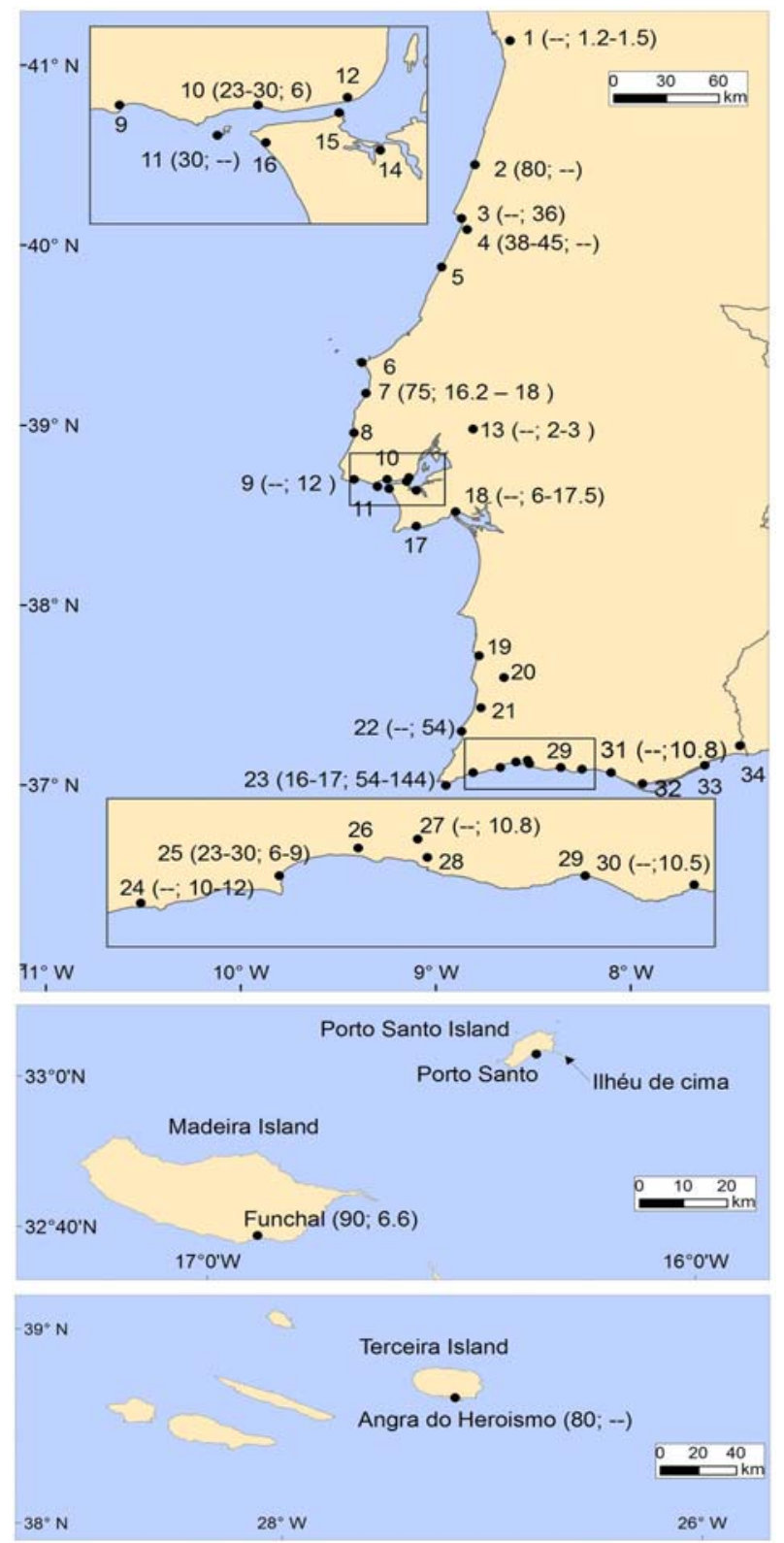

Fig. 4 Location of the places with tsunami accounts in Portugal. Upper, inset plot shows details in Lisbon, and lower inset plot shows details in Lagos. Middle plot shows details in Madeira. Lower plot shows details in Azores. Also included is (travel time in minutes; run-up in meters), as summarized in Table 2. 
Caribbean, Ireland, UK, Spain and Morocco is presented in Table 1 . The eyewitnesses reported tsunami travel times of 560 minutes in Barbados, 598 minutes in Antigua, and 620 minutes in Santiago de Cuba, which are consistent with their location (as presented in Fig. 1).

However, there is one account that reported an arrival time at Barbados 2 hours earlier. In general the run-ups vary between 1.5-7.5 m, with duration of perturbation till $10 \mathrm{pm}$, and period of 5-10 minutes.

The eyewitnesses reported the tsunami arriving to Ireland and UK about four to five hours after the earthquake (Fig. 2), with run-ups of about $2 \mathrm{~m}$, and periods of 10 minutes. At the St. Michael Mount there were four waves. There were no reports related to the tsunami parameters in Mousehole.

Table 1 Summary of the tsunami parameters in the Caribbean, Ireland, UK, Spain and Morocco.

\begin{tabular}{|c|c|c|c|c|c|c|}
\hline Place & Travel time (min) & Initial response & Run-up (m) & No. waves & Period & Duration of perturbation \\
\hline Santiago de Cuba & 620 & - & - & - & - & - \\
\hline Saba & - & - & $6.3-7.5$ & - & - & - \\
\hline St. Marin & - & $-4.5 \mathrm{~m}$ & - & - & - & - \\
\hline Antigua & 598 & - & 3.6 & Several & $5 \mathrm{~min}$ & Until 10 pm \\
\hline Barbados & $454-560$ & - & $1.5-6$ & 32 & $15 \mathrm{~min}$ & $2 \mathrm{pm}-10 \mathrm{pm}$ \\
\hline Kinsale & $260-320$ & Uplift & 1.65 & Several & $10 \mathrm{~min}$ & Till 3 am \\
\hline Mount & $255-260$ & Uplift & $1.5-1.8$ & 4 & $10 \mathrm{~min}$ & $2 \mathrm{pm}-7: 30 \mathrm{pm}$ \\
\hline Penzance & 305 (320 Max) & Subsidence & 2.4 & - & - & - \\
\hline Newlyn & $255-305$ & Uplift & 3 & - & $10 \mathrm{~min}$ & - \\
\hline St. Ives & - & - & $2.4-2.7$ & - & - & - \\
\hline Hayle & $315-360$ & - & 2.1 & - & - & - \\
\hline Plymouth & 360 (380 Max) & - & - & - & $8 \mathrm{~min}$ & 30 minutes \\
\hline Santander & - & Subsidence & - & 3 & - & - \\
\hline Viveiro & - & Uplift & - & 3 & - & - \\
\hline Betanzos & - & - & - & - & - & All day \\
\hline Coruna & - & Uplift & - & 4 & $15 \mathrm{~min}$ & Till the night \\
\hline Corcubion & 135 & - & - & - & - & - \\
\hline Pontevedra & - & Uplift & $2-3$ & 3 & - & - \\
\hline Ayamonte & 60 & Uplift & - & 5 & - & - \\
\hline Lepe & $30(1)$ & Uplift & - & 3 & - & - \\
\hline Huelva & 55 & Uplift & - & - & - & Till midnight \\
\hline Mouguer & - & - & - & 1 & - & - \\
\hline S. Barrameda & 60 & Uplift & - & - & - & - \\
\hline S. Regla & 75 & Uplift & - & 2 & - & - \\
\hline P. Santa Maria & 65 & Uplift & 8 & - & - & - \\
\hline Carraca & 75 & - & - & - & - & All afternoon \\
\hline Cadiz & $\begin{array}{l}70-75 \\
78\end{array}$ & $\begin{array}{l}\text { Subsidence } \\
\text { Uplift }\end{array}$ & 15 & 4 or 5 & - & Till midnight \\
\hline Sancti-Petri & $45(1)$ & Uplift & - & - & - & - \\
\hline Algeciras & $45(1)$ & - & - & - & - & Till the night \\
\hline Marbella & $60(1)$ & - & - & - & - & - \\
\hline Ceuta & - & - & - & - & - & Till the next day \\
\hline Canaria & - & - & - & 3 & - & - \\
\hline Tanger & - & - & - & 18 & - & Till 6 pm \\
\hline Sale & $\begin{array}{l}33-40 \\
43-50\end{array}$ & $\begin{array}{l}\text { Subsidence } \\
\text { Uplift }\end{array}$ & - & - & - & - \\
\hline Safi & - & - & - & - & - & 10 am till $6 \mathrm{pm}$ \\
\hline Agadir & - & - & - & - & - & 10 am till $6 \mathrm{pm}$ \\
\hline
\end{tabular}

(1) travel times not reliable. 
In general the tsunami took more than one hour to reach the Gulf of Cadiz, therefore some reports were considered not reliable (Lepe, Sacti-Petri, Algeciras and Marbella). The run-up reports are scarce, only being reported as 2-3 $\mathrm{m}$ in Pontevedra, $8 \mathrm{~m}$ in Puerto de Santa Maria and $15 \mathrm{~m}$ in Cadiz (Fig. 3). There was one major wave reported in Mouguer, but in most places 3 major waves were observed. The duration of the mean sea level perturbation lasted for about 10 hours. In Spain there is no description of tsunami parameters in: Bilbau, Ferrol, Redondela, Baiona, Bonanza, Rota, Puerto Real, San Fernando, Conil, Vejer de la Fronteira, Tarifa, Estepona and Lanzarote, and in Morocco there is no description of tsunami parameters in: Arzila, Larache, Mehdiya and Marrakech.

The summary of the tsunami parameters in Portugal is presented in Table 2 , and the location of the places is shown in Fig. 4. Since the historical accounts in Portugal are vast and very well documented in most of the coastal municipalities, civil parishes and beaches, data in mainland Portugal were compiled from previous studies conducted by the authors [1, 9], except in Benavente (Point-13). However, there is no description of tsunami parameters in: Peniche (6), Lisbon (12), Seixal (14), Almada (15), Costa de Caparica (16), Sesimbra (17), Vila Nova de Mil Fontes (19), Odemira (20), Odeceixe (21), Alvor (26),

Table 2 Summary of the tsunami parameters in Portugal. In mainland, except in 13-Benavente, data were compiled from Ref. [1], [9].

\begin{tabular}{|c|c|c|c|c|c|c|}
\hline Place & Travel time (min) & Initial response & Run-up (m) & No. waves & Period & $\begin{array}{l}\text { Duration of } \\
\text { perturbation }\end{array}$ \\
\hline 1-Oporto & - & Uplift & $>1.2-1.5$ & - & $15 \mathrm{~min}$ & More than $4 \mathrm{~h}$ \\
\hline 2-Mira & 80 & Uplift & - & Several & $30 \mathrm{~min}$ & 1h 30 m \\
\hline 3-Figueira da Foz & - & Uplift & 36 & 3 & $2 \mathrm{~h}$ & Till sunset \\
\hline 4-Lavos & $38-45(1)$ & Uplift & - & 1 & - & - \\
\hline 5-Viera & - & - & - & 1 & - & - \\
\hline 7-A-dos-Cunhados & 75 & Uplift & $16.2-18(2)$ & 3 & - & All afternoon \\
\hline 8-Ericeira & - & - & - & - & - & All day \\
\hline 9-Cascais & - & Uplift & 12 & 3 & Brief time & - \\
\hline 10-Carnaxide & $23-30$ & Uplift & 6 & 3 & - & - \\
\hline 11-Bugio light house & 30 & Uplift & - & 3 & - & - \\
\hline 13- Benavente & - & - & $2-3$ & 3 & - & - \\
\hline 18-Setubal & - & - & $6-17.5$ & 3 & - & - \\
\hline 22-Aljezur & - & Subsidence Uplift & $\begin{array}{l}-54 \\
\text { N: 3.6; S: } 54 \text { (2) }\end{array}$ & - & Few minutes & - \\
\hline 23-Sagres (Sao Vicente Cape) & $\begin{array}{l}6-7 \\
16-17\end{array}$ & Subsidence Uplift & $\mathrm{N}:-11$; E: -14 & - & - & - \\
\hline 23- Sagres (Beliche Fortress) & - & - & $54(2)$ & 3 & - & - \\
\hline $\begin{array}{l}\text { 23-Sagres (Sagres } \\
\text { Fortress) }\end{array}$ & - & $\begin{array}{l}\text { Subsidence } \\
\text { Uplift }\end{array}$ & 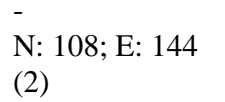 & - & - & - \\
\hline 23-Sagres (Martinhal beach) & - & - & - & 3 & - & - \\
\hline 24-Budens & - & Uplift & $10-12$ & - & - & - \\
\hline 25-Lagos & $23-30$ & Uplift & $6-9$ & - & - & - \\
\hline 27-Portimao & - & Uplift & 10.8 & - & - & - \\
\hline 30-Albufeira & - & Uplift & 10.5 & 3 & Few minutes & Till 4 pm \\
\hline 31-Quarteira & - & Uplift & 10.8 & 5 & - & - \\
\hline P. Santo & - & Uplift & - & - & - & - \\
\hline Funchal & 90 & Uplift & 6.6 & 4 or 5 & - & - \\
\hline A. Heroismo & 80 & - & 3 & 3 & - & - \\
\hline
\end{tabular}

(1) travel times not reliable; (2) run-ups at the cliffs. 
Ferragudo (28), Armação de Pera (29), Faro (32), Tavira (33) and Castro Marim (34).

Portugal is the first country hit by the tsunami, in less than 30 minutes after the earthquake, and within 90 minutes the coastline was hit by the tsunami. In Madeira and Azores Islands the tsunami reached within 90 and 80 minutes, respectively. The initial response is uplift all over the Portuguese coastline, except at Aljezur (22) and Sagres (23), where very steep cliffs are located. At Oporto (1) it was observed the lowest run-up of about $1.5 \mathrm{~m}$. In general, run-ups range between 6-10 $\mathrm{m}$, on the beaches. However, extreme run-ups were observed by the eyewitnesses on the cliffs: Aljezur-Arrifana Tip (22), Sagres (23). At A-dos-Cunhados-Porto Novo beach (7) and Figueira da Foz (3) the witnesses also report unexpected high run-ups of about $18 \mathrm{~m}$ and $36 \mathrm{~m}$, respectively. There were 3 major waves (Portugal mainland and Azores Island), with exceptions at Mira beach (2), where several waves were observed, at Lavos (4) and Viera beach (5), where only 1 major wave was reported, and at Quarteira (31), where 5 major waves were described by the witnesses. The periods range from a few minutes to about 30 minutes. The eyewitnesses describe the duration of the sea surface perturbation for several hours after the earthquake.

\subsection{Damage and Fatalities}

The summary of damage and fatalities in the Caribbean, Ireland, UK, Spain and Morocco is presented in Table 3. In general the tsunami inundated the coastal areas of the Caribbean, Ireland and UK causing minor damage, especially on the ports, and no fatalities were reported.

In Spain the combined effect of the earthquake and the tsunami caused about 2,000 fatalities [16, 22]. The tsunami inundated most of the beaches and coastal areas of Spain, causing significant damage. However there was no damage in: Bilbau, Santander, Viveiro, Ferrol, Betanzos, Coruna, Corcubion, Pontevedra,
Lepe, Moguer, Convent of N.S. Regla, Carraca, Algeciras, Estepona, Marbella, Ceuta and Santa Cruz de Tenerife. This situation might be related to the wave energy dispersion [4], since these areas are located far from the tsunami source area, or located inside estuaries and bays, or the areas are located on high ground.

In Morocco there were many dead and damage in all the reported places, as summarized in Table 3. In Tanger, Arzila, Larache and Mehdiya the impact was due to the combined effect of the earthquake and tsunami. Furthermore, the tsunami reached Marrakech, which is located more than $200 \mathrm{~km}$ from the coastline.

The summary of damages and fatalities in Portugal is presented in Table 4. The eyewitness' accounts show the country was not affected in a uniform way. Instead, the reports show there was no damage and fatalities at Oporto, Mira, Figueira da Foz, Vieira, Benavente, Odemira, Odeceixe and Faro. On the other hand, the most risk-prone areas, where damage and fatalities were reported, were Peniche (6), the Lisbon Metropolitan Area and seven coastal areas in the south of Portugal—Lagos (25), Portimão (27), Armação de Pera (29), Albufeira (30), Quarteira (31), Tavira (33) and Castro Marim (34). Like in Spain, this might be related to distance to the tsunami source area, and local geographic conditions.

The exact number of fatalities will probably never be known since 18th century census were not as accurate as today, and did not consider children under seven years old. Nevertheless, the accounts show a total number of 13,871. Lisbon and Setubal suffered more due to the earthquake, fire and tsunami: about 10,000 dead (about 9\%) and about 2,000 dead (about 17\%), respectively. However, Castro Marim had the highest percentage of fatalities (about 55\%), followed by Cascais (less than 29\%), Lagos (17\%) and Albufeira (more than 10\%). The structural damaged on buildings in Lisbon was estimated at about $82 \%$ [10]. 
Table 3 Summary of damages in the Caribbean, Ireland, UK, Spain and Morocco.

\begin{tabular}{|c|c|c|}
\hline Place & Damage & Fatalities \\
\hline S. Cuba & Inundated Santiago de Cuba & - \\
\hline Martinique & Inundated the upper rooms of houses; destroyed much coffee & - \\
\hline Barbados & Inundated quays and streets & - \\
\hline Kinsale & $\begin{array}{l}\text { Broken the cables of two sloops, each moor'd with } 2 \text { anchors; damaged several boats; } \\
\text { Inundated the market }\end{array}$ & - \\
\hline Plymouth & Drove several ships from their moorings, and broke some cables & - \\
\hline Redondela & Inundated the warehouses and fishery tools & - \\
\hline Baiona & Boat cape sized on the ria & - \\
\hline Ayamonte & Inundated the beaches and made damaged in the fishery & - \\
\hline Huelva & Inundated some streets & - \\
\hline S. Barrameda & Inundated the streets; destroyed 5 fishery vessels & - \\
\hline Bonanza & Ship loaded with wheat was pushed to a sand bank & - \\
\hline Chipiona & Inundated the beach and the streets & - \\
\hline Rota & Broke up the pier and entered on same streets & - \\
\hline $\begin{array}{l}\text { P. Santa } \\
\text { Maria }\end{array}$ & Inundated the houses; damaged the pier & - \\
\hline Puerto Real & Introduced smoothly on the streets & - \\
\hline Cadiz & $\begin{array}{l}\text { Carried pieces of 8-10 ton weight, } 35.7-45.7 \mathrm{~m} \text { from the wall; carried away the sand and } \\
\text { walls, but left the houses standing }\end{array}$ & - \\
\hline San Fernando & Severe damages on the beach houses & - \\
\hline Sancti-Petri & Inundated the river and diverted the boats & - \\
\hline Conil & Entered 6,750 m inland; drowned 599 head of cattle & - \\
\hline V. Fronteira & Entered 6,750 m inland & - \\
\hline Tarifa & Wreck of 3 vessels & - \\
\hline Lanzarote & Destroyed some salt-marshs & - \\
\hline P. Canarias & A chapel was inundated & - \\
\hline Tanger & $\begin{array}{l}\text { Passed the rampart and inundated the fields, destroyed many vessels; when it lowered } \\
\text { down left the streets and the fields full of debris and fish; damaged many houses; when } \\
\text { it lowered down left the streets and the fields full of debris and fish }\end{array}$ & $\begin{array}{l}\text { Many people (earthquake } \\
\text { and tsunami) }\end{array}$ \\
\hline Arzila & $\begin{array}{l}\text { Passed the rampart and inundated the fields, destroyed many vessels; when it } \\
\text { lowered down left the streets and the fields full of debris and fish; inundated more than } \\
\text { half of the city, damaging many houses; launched into the middle of the city a big vessel } \\
\text { that broke apart and opened in the middle, nobody from the crew died. }\end{array}$ & $\begin{array}{l}\text { Many people (earthquake } \\
\text { and tsunami) }\end{array}$ \\
\hline Larache & $\begin{array}{l}\text { Passed the rampart and inundated the fields, destroyed many vessels; when it lowered } \\
\text { down left the streets and the fields full of debris and fish; damaged many houses. }\end{array}$ & $\begin{array}{l}\text { Many people (earthquake } \\
\text { and tsunami) }\end{array}$ \\
\hline Mehdiya & $\begin{array}{l}\text { Passed the rampart and inundated the fields, destroyed many vessels; when it lowered } \\
\text { down left the streets and the fields full of debris and fish; damaged many houses. }\end{array}$ & $\begin{array}{l}\text { Many people (earthquake } \\
\text { and tsunami) }\end{array}$ \\
\hline Sale & $\begin{array}{l}\text { Inundated streets and warehouses; destroyed at least } 5 \text { boats; when it lowered down left } \\
\text { the streets and the fields full of debris and fish; big number of camels drowned. }\end{array}$ & $\begin{array}{l}\text { More than } 200 \text { dead, in } 3 \\
\text { boats. Many people died } \\
\text { inside the houses, on the } \\
\text { boats, and on the shore } \\
\text { watching the waves }\end{array}$ \\
\hline Safi & $\begin{array}{l}\text { Destroyed many vessels; destroyed coastal constructions and ports; when it lowered } \\
\text { down left the streets and the fields full of debris and fish. }\end{array}$ & Many people \\
\hline Marrakech & The river inundated the city, killing many animals. & Many people \\
\hline Agadir & $\begin{array}{l}\text { Destroyed many vessels; destroyed coastal constructions and ports; when it lowered } \\
\text { down left the streets and the fields full of debris and fish. }\end{array}$ & Many people \\
\hline
\end{tabular}


Table 4 Summary of damage and fatalities in Portugal. In mainland, data were compiled from Ref. [10].

\begin{tabular}{|c|c|c|c|c|c|c|}
\hline \multirow{2}{*}{ Place } & \multirow{2}{*}{ Damage } & \multicolumn{2}{|c|}{ Fatalities } & \multicolumn{3}{|c|}{ Population data (older than 7 years old) } \\
\hline & & Number & $\%$ & $1755 \quad 175$ & 1758 & \\
\hline 1-Oporto & - & 0 & 0 & - & - & 1,857 \\
\hline 2- Mira & - & 0 & 0 & - & 2,219 & - \\
\hline 3-Figueira da Foz & - & 0 & 0 & - & 900 & - \\
\hline 4-Lavos & - & 0 & 0 & - & 1,537 & - \\
\hline 5-Viera & - & 0 & 0 & - & 622 & - \\
\hline 6-Peniche & $\begin{array}{l}\text { Destroyed the rampart, houses and } \\
\text { vessels }\end{array}$ & $>50$ & $>1.1$ & - & - & 4,673 \\
\hline 7-A-dos-Cunhados & Destroyed the Penafirme convent & 0 & 0 & - & 575 & 650 \\
\hline 8-Ericeira & Boats were washed away & 0 & 0 & - & - & 1,255 \\
\hline 9-Cascais & $\begin{array}{l}\text { More than } 50 \text { fishery vessels and boats } \\
\text { were destroyed. Almost all buildings } \\
\text { collapsed (1) }\end{array}$ & $\begin{array}{l}>624-664 \\
(1)\end{array}$ & $>24.9-26.7$ & - & $2,484-2,505$ & 2,592 \\
\hline 10-Carnaxide & Destruction of Cruz Quebrada bridge & 1 & 0.05 & - & - & 1,944 \\
\hline 11-Bugio light house & Debris washed away & $\begin{array}{l}\text { People } \\
\text { dragged } \\
\text { away }\end{array}$ & (4) & - & - & - \\
\hline 12-Lisbon & Destruction of many buildings (2) & $\begin{array}{l}10,000(2, \\
3)\end{array}$ & 6.4-9.1 & 109,754-157,192 & 50,808 & 156,254 \\
\hline 13-Benavente & - & 0 & 0 & - & 2,208 & - \\
\hline 14-Seixal & - & Many (1) & (4) & - & - & 1,018 \\
\hline 15-Almada & - & $>26(1)$ & $>1.0$ & - & - & 3,867 \\
\hline 16-Caparica & - & 5 & 0.3 & - & - & 1,484 \\
\hline 17-Sesimbra & Destroyed the vessels & 0 & 0 & - & - & 1,534 \\
\hline 18-Setubal & $\begin{array}{l}\text { Destruction of the rampart, many } \\
\text { vessels and buildings ( } 2 \text { ) }\end{array}$ & $>2,000(2)$ & $>16.9$ & - & - & 11,842 \\
\hline $\begin{array}{l}\text { 19-Vila Nova de Mil } \\
\text { Fontes }\end{array}$ & Destroyed 3 beach houses & 0 & 0 & - & - & 364 \\
\hline 20-Odemira & - & 0 & 0 & - & - & 1,140 \\
\hline 21-Odeceixe & - & 0 & 0 & - & - & 320 \\
\hline 22-Aljezur & Destroyed the fortress & 0 & 0 & - & - & 1,044 \\
\hline 23-Sagres & Destroyed the vineyards & 0 & 0 & - & - & 198 \\
\hline 24-Budens & $\begin{array}{l}\text { Destroyed the Almadena fishing net, } \\
\text { with } 50 \text { heavy anchors }\end{array}$ & 0 & 0 & - & - & 344 \\
\hline 25-Lagos & $\begin{array}{l}\text { Destruction of the rampart, many } \\
\text { vessels and buildings ( } 2 \text { ) }\end{array}$ & $>300(1,3)$ & $>17.4$ & - & - & 1,723 \\
\hline 26-Alvor & Razed the chapel & 0 & 0 & - & - & 892 \\
\hline 27-Portimão & $\begin{array}{l}\text { Destroyed the salt marshes, market } \\
\text { gardens, houses, and } 3 \text { water-mills. On } \\
\text { the backwash razed de São João } \\
\text { Fortress and the Capuchos Convent }\end{array}$ & 38 & 2.1 & - & - & 1,802 \\
\hline 28-Ferragudo & Destroyed $1 / 3$ of houses & 0 & 0 & - & - & 566 \\
\hline 29-Armação de Pera & $\begin{array}{l}\text { Destroyed the fortress and many } \\
\text { houses }\end{array}$ & $60-84$ & $5.8-8.1$ & - & - & 1,042 \\
\hline 30-Albufeira & $\begin{array}{l}\text { Destroyed a neighborhood and the } \\
\text { rampart }\end{array}$ & $>227$ & $>10.4$ & - & - & 2,189 \\
\hline 31-Quarteira & - & $28-52$ & $1.5-2.8$ & - & - & 1,841 \\
\hline 32-Faro & - & 0 & 0 & - & - & 6,951 \\
\hline 33-Tavira & Significant damage (1) & $250(1)$ & 2.6 & - & - & 9,494 \\
\hline 34-Castro Marim & Everything was razed (1) & $>180(1)$ & $>55.2$ & - & - & 326 \\
\hline P. Santo & $\begin{array}{l}\text { Inundated the town, and only one } \\
\text { house was overthrow by the sea }\end{array}$ & 0 & 0 & - & - & - \\
\hline Funchal & $\begin{array}{l}\text { On the north of the island the sea } \\
\text { retreated leaving on dry land a large } \\
\text { quantity of fish }\end{array}$ & 0 & 0 & - & - & - \\
\hline A. Heroismo & Demolishing many houses & 0 & 0 & - & - & - \\
\hline
\end{tabular}

(1) damage/fatalities due to earthquake and tsunami; (2) damage/fatalities due to earthquake, fire and tsunami; (3) includes fatalities during the month of November; (4) unknown data. 


\section{Conclusions}

The 1755 Lisbon Tsunami affected a wide area of the Atlantic North, hitting the coastal areas of Portugal (mainland and Madeira and Azores Islands), Morocco and Spain. It also reached as far as Ireland, UK and the Caribbean region. The compilation of the original accounts in these areas provided important data to conduct a comprehensive analysis of this historical event, especially to analyze the tsunami parameters as well as damage and fatalities.

The tsunami travel times reported by the eyewitnesses show that Portugal is hit in less than 30 minutes after the earthquake and within 90 minutes the entire coastline is hit. In Morocco and Gulf of Cadiz the initial response is a subsidence, but the first tsunami wave arrives about one hour after the earthquake. The tsunami continues propagating, arriving at Funchal (Madeira Islands) about 90 minutes, and to Ireland and UK within about five hours. The tsunami numerical model results are validated by these reports [1, 4-5]. The tsunami would take about 9-10 hours to reach the Caribbean region. Therefore, in the disaster prevention point of view for a future tsunami event, both historical accounts and tsunami numerical model results should be taken into consideration to allow the coastal communities to safely evacuate, even without a reliable tsunami warning system operating.

In general the observed tsunami run-ups were between 1.5-6 $\mathrm{m}$ in most areas. However, extreme run-ups were reported by the witnesses in Spain (Cadiz) and in Portugal (at the cliffs of Arrifana Tip, and Sagres, as well as the beaches of Figueira da Foz and Porto Novo). The reported values should be taken with some caution because the witnesses were not tsunami experts. However, the tsunami numerical model results [1, 4-6] showed local amplification on these places, even though they were underestimated. Thus, the numerical model results prove that these particular coastal areas are more hazardous to a future tsunami event than others.

The eyewitnesses report several waves, being three waves in most of the places, period wave of about 10 minutes, and duration of the sea surface perturbation for several hours. Although the numerical model results in the regional scale [1, 4-5], do not reproduce the correct number of waves, a more local approach [7] has validated the three major waves in Setubal (Portugal).

In the Caribbean, Ireland and UK, the eyewitnesses reported minor damage, and no fatalities. In Spain there were about 2,000 fatalities [16, 22] to the earthquake and tsunami. There was no damage in 17 of the 31 places where the tsunami was reported, but in general there was significant damage on the coast: Many boats and salt marshes were destroyed, damage on the fishery structures like piers and warehouses, inundation of the streets and in Conil 599 head of cattle have dead.

In Morocco many people have died as well as many camels, and significant damage was observed in all the reported places, including Marrakech which is located about $200 \mathrm{~km}$ inland.

In Portugal, the accounts show the geographical distribution of damage and fatalities is not uniform, since in some areas significant damage and fatalities were reported, while in the neighbor municipalities no damage at all was reported. This situation might be related to the wave energy dispersion [4], since these areas are located far from the tsunami source area, or located inside estuaries and bays, or the areas are located on high ground. As pointed out by [4], all the Portuguese places where damage and fatalities were reported are located below $18 \mathrm{~m}$ high. Therefore, further research should be carried out by using the tsunami numerical model and field surveys in order to fully understand these discrepancies. Still, damage and fatalities were reported in Peniche, the Lisbon Metropolitan Area and seven coastal areas in the south of Portugal (Lagos, Portimão, Armacao de Pera, Albufeira, Quarteira, Tavira and Castro Marim). The 
exact number of fatalities will probably never be known since 18th century census were not as accurate as today, and did not consider children under seven years old. Nevertheless, the accounts show that more than 14,000 people have died. Lisbon and Setubal suffered more due to the earthquake, fire and tsunami: about 10,000 dead (about 9\%) and about 2,000 dead (about 17\%), respectively. However, Castro Marim had the highest percentage of fatalities (about 55\%), followed by Cascais (less than 29\%), Lagos (17\%) and Albufeira (more than 10\%).

This study shows there was significant damage and fatalities registered in Portugal (Peniche, the Lisbon Metropolitan Area, Lagos, Portimão, Armação de Pera, Albufeira, Quarteira, Tavira and Castro Marim), Spain (Cadiz) and in all Morocco coastline, including Marrakech which is located about $200 \mathrm{~km}$ inland. The combination between such devastating impact and tsunami travel times of less than 60 minutes shows that these coastal areas are the most tsunami risk-prone for a future tsunami. Therefore, although most coastal areas have been developing significantly since the 18th century, spatial planning agents and stakeholders should have tsunami mitigation programs in order to safely evacuate their coastal communities. Furthermore, knowledge about past tsunami events proved to be a very important tool to allow a safe evacuation of the coastal communities during the 2011 Tohoku Tsunami, because even the malfunction of the tsunami warning system many people remembered the 1960 Chile Tsunami [23-24].

\section{References}

[1] Santos, A., Koshimura, S., and Imamura, F. 2009. “The 1755 Lisbon Tsunami: Tsunami Source Determination and Its Validation.” Jour. Dis. Res. 4 (1): 41-52.

[2] Reid, H. 1914. "The Lisbon Earthquake of November 1, 1755.” Bul. Seis. Soc. Am. IV (2): 53-80.

[3] Synolakis, C., and Okal, E. 2005. “1992-2002: Perspective on a Decade of Post-tsunami Surveys, Tsunamis: Case Studies and Recent Developments.” Adv. Nat. Tech. Haz. 23: 1-30.

[4] Santos, A. 2008. "Tsunami Hazard Assessment in Portugal by the Worst Case Scenario: The November 1st, 1755 Lisbon Tsunami.” Ph.D. thesis, Tohoku University.

[5] Santos, A., Zêzere, J. L., and Agostinho, R. 2011. "The 1755 Tsunami and the Hazard Assessment in Portugal Mainland.” In Proceedings of the VIII CGP. http://riskam.ul.pt/images/pdf/Risco_68-375-1.pdf.

[6] Santos, A., Fonseca, N., Pereira, S., Zêzere, J. L., and Koshimura, S. 2012. "Tsunami Risk Assessment at Figueira da Foz, Portugal.” 15 WCEE. http://riskam.ul.pt/images/pdf/paper_1931.pdf.

[7] Santos, A., and Koshimura, S. 2013a. "Tsunami Hazards at Setubal Urban Area Considering the 1755 Lisbon Tsunami." In Proceedings of the IX CGP. ISBN: 978-972-99436-6-9.

http://riskam.ul.pt/images/pdf/ix_cgp_santos_koshimura_ 2013_hazard.pdf.

[8] Santos, A., Tavares, A. O., and Emidio, A. 2014. "Comparative Tsunami Vulnerability Assessment of an Urban Area: An Analysis of Setúbal City, Portugal.” Applied Geography 19-29. http://dx.doi.org/10.1016/j.apgeog. 2014.08.009.

[9] Santos, A., and Koshimura, S. 2013b. "Estimating the Tsunami Parameters of the 1755 Lisbon Tsunami in Portugal by the Interpretation of the Historical Accounts.” In Proceedings of the IX CGP. ISBN: 978-972-99436-6-9.

http://riskam.ul.pt/images/pdf/ix_cgp_santos_koshimura_ 2013.pdf.

[10] Santos, A., and Koshimura, S. 2015. "The Impact of the 1755 Lisbon Tsunami in Portugal: Historical Review.” In Proceedings of the RIMMA. (submitted)

[11] O’Loughlin, K. F., and Lander, J. F. 2003. Caribbean Tsunamis, a 500-year History from 1498-1998. Norwell, MA: Kluwer Academic Publishers.

[12] Sousa, L. 1919. "The November 1, 1755 Earthquake in Portugal and a Demographic Study.” Geological Services 1: 1-277.

[13] Nicola, L. 1756. "Letter XXIII from L. Nicola to James Simon, Esq; F.R.S.” Phil. Trans. Roy. Soc. London 49 (58): 391-3.

[14] Borlase, W. 1756. "From the Rev. William Borlase, A.M.F.R.S. to the Rev. Charles Lyttleton, L.L. D. Dean of Exeter.” Phil. Trans. Roy. Soc. London 49 (58): 373-8.

[15] Huxham, J. 1756. "Letter from John Huxham, M.D.F.R.S. to Mr. William Watson, F.R.S.” Phil. Trans. Roy. Soc. London 49 (58): 371-3.

[16] Solares, J., and Arroyo, A. 2005. "The 1755 Earthquake in Spain.” In 1755-The Great Lisbon Earthquake 1: 237-64.

[17] Luque, L., Lario, J., Zazo, C., Goy, J., Dabrio, C., and Silva, P. 2001. "Tsunami Deposits as Paleoseismic Indicators: Examples from the Spanish Coast." In the 
Proceedings of The Spanish Geological Record 36 (3-4): 197-211.

[18] Bewick, B. 1756. "An Account of the Earthquake at Cadiz, Novem. 1, 1755, in a Letter from Mr. Benjamin Bewick, Merchant there, to Mr. Joseph Paice, Merchant in London.” Phil. Trans. Roy. Soc. London 49 (59): 424-7.

[19] Abdelaziz, C. 2005. "The Effects of the November 1, 1755 Lisbon Earthquake in Morocco.” In 1755-The Great Lisbon Earthquake 1: 265-94.

[20] Sousa, L. 1928. "The November 1, 1755 Earthquake in Portugal and a Demographic Study.” Geological Services 3: 479-949.

[21] Heberden, T. 1756. "An Account of the Earthquake in the Island of Madeira, Nov. 1, 1755, in a Letter from Dr. Tho
Heberden, to His Brother Dr. William Heberden, F.R.S.” Phil. Trans. Roy. Soc. London 49 (59): 432-4.

[22] Solares, J., and Arroyo, A. 2004. "The Great Historical 1755 Earthquake. Effects and Damage in Spain.” Jour. Seism. 8: 275-94.

[23] Santos, A., and Zêzere, J. L. 2012. "Analysis of the 2011 Tohoku tsunami." In the Proceedings of the 12th National Meeting of Geomorpholy. ISBN: 978-84-86116-54-5.

http://riskam.ul.pt/images/pdf/xiirng_santos_zezere_2011 pdf.

[24] Santos, A., and Queirós, M. 2013. "The 2011 Tohoku Tsunami: Analyzing the Evacuation of the Survivors.” Abstract at IGU 2013, Kyoto Regional Conference. http://riskam.ul.pt/images/pdf/igu_abstracts_survivors.pdf. 